\title{
Hubungan Pengetahuan Dengan Kepatuhan Ibu Hamil Dalam Mengkonsumsi Tablet Zat Besi (Fe) Di Wilayah Kerja Puskesmas Lawanga Kabupaten Poso
}

\author{
Hastanti \\ Sekolah Tinggi Ilmu Kesehatan Husada Mandiri Poso \\ Email : hastanti.tanti@yahoo.com
}

\begin{abstract}
Background: Iron $(\mathrm{Fe})$ tablets as supplements given to pregnant women according to the rules must be consumed every day, but for various reasons such as knowledge, attitudes and actions of pregnant women that are not good, side effects of tablets caused by the tablet can cause someone to lack of compliance with iron $(\mathrm{Fe})$ tablet consumption correctly so that the purpose of administering the tablet is not achieved. Objective: To determine the relationship of knowledge with the compliance of pregnant women in consuming iron tablets (Ferossus) in the working area of Lawanga health center Poso. Research Methods: The type of research used was descriptive analytic with a cross sectional approach. The number of respondents was 46 pregnant women using total sampling technique. Data were analyzed using Chi-square test. The results of the study: showed that $56.5 \%$ of respondents had good knowledge about substance bezi (Fe) tablets, $60.9 \%$ of respondents obeyed consuming iron $(\mathrm{Fe})$ tablets. There is a relationship of knowledge with the compliance of pregnant women in consuming iron $(\mathrm{Fe})$ tablets $\mathrm{p}$ value $=0,000(\mathrm{p}$ $<0.05$ ). Conclusion: There is a relationship between knowledge with compliance of pregnant women in consuming iron (Fe) tablets in Lawanga health center Poso district.
\end{abstract}

Keywords: Knowledge, adherence, iron tablets (fe)

\begin{abstract}
Abstrak
Latar Belakang: Tablet zat besi (Fe) sebagai suplemen yang diberikan pada ibu hamil menurut aturan harus dikonsumsi setiap hari, namun karena berbagai alasan misalnya pengetahuan, sikap dan tindakan ibu hamil yang kurang baik, efek samping tablet yang ditimbulkan tablet tersebut dapat menyebabkan seseorang untuk kurang mematuhi konsumsi tablet zat besi $(\mathrm{Fe})$ secara benar sehingga tujuan dari pemberian tablet tersebut tidak tercapai.

Tujuan: Mengetahui Hubungan Pengetahuan Dengan Kepatuhan Ibu Hamil Dalam Mengkonsumsi Tablet Zat Besi (Ferossus) Di Wilayah Kerja Puskesmas Lawanga Kabupaten Poso. Metode Penelitian: Jenis penelitian yang digunakan adalah deskriptif analitik dengan pendekatan cross sectional. Jumlah responden sebanyak 46 ibu hamil dengan menggunakan tehknik total Sampling. Data dianalisa dengan menggunakan uji Chi-square.

Hasil penelitian : Menunjukkan bahwa 56,5\% responden memiliki pengetahuan baik, tentang tablet zat bezi $(\mathrm{Fe})$, Sebesar $60,9 \%$ responden patuh mengkonsumsi tablet zat besi $(\mathrm{Fe})$. Ada hubungan Pengetahuan dengan Kepatuhan Ibu Hamil dalam Mengkonsumsi Tablet Zat Besi (Fe) nilai $p=0,000(p<0,05)$ Kesimpulan: Ada hubungan antara Pengetahuan dengan Kepatuhan Ibu Hamil dalam Mengkonsumsi Tablet Zat Besi (Fe) di Puskesmas Lawanga Kabupaten Poso.
\end{abstract}

Kata kunci : Pengetahuan, kepatuhan, tablet zat Besi (fe) 


\section{PENDAHULUAN}

Indikator utama dalam upaya pembangunan kesehatan adalah dengan meningkatkan derajat kesehatan masyarakat yang diantaranya adalah menurunkan Angka Kematian Ibu (AKI). Dimana AKI yang dimaksud adalah yang berkaitan dengan kehamilan, persalinan, dan nifas di Indonesia sebesar 359 per 100.000 kelahiran hidup (1).

Menurut WHO, 40\% kematian Ibu di negara berkembang berkaitan dengan anemia dalam kehamilan. Frekuensi ibu hamil di Indonesia yang mengalami anemia masih sangat tinggi yaitu 63,5\% dibandingkan di Amerika hanya 6\%. Anemia adalah kondisi ibu dengan kadar haemoglobin (Hb) dalam darahnya kurang dari 12 gr\%. Sedangkan anemia dalam kehamilan adalah kondisi ibu dengan kadar haemoglobin dibawah $11 \mathrm{gr} \%$ pada trimester I dan III atau kadar <10,5 gr\% pada trimester II (2).

Berdasarkan Profil Kesehatan Indonesia 2011, prevalensi anemia ibu hamil di Indonesia 40,1\% dan pada tahun 2013 turun menjadi 24,5\%. Namun demikian keadaan ini mengindikasikan bahwa anemia gizi besi masih menjadi masalah kesehatan masyarakat. Pada tahun 2013 proporsi pemberian $\mathrm{Fe} 1$ 76,9\% dan $\mathrm{Fe} 3$ 68,7\%. Provinsi dengan proporsi tertinggi adalah Provinsi Bali (90,43\%), Kep. Bangka Belitung $(84,85 \%)$ dan Nusa Tenggara Barat $(81,51 \%)$. Sedangkan proporsi terendah adalah Provinsi Papua $(31,57 \%)$, dan Sulawesi Barat (38,19\%) (1). Sebagian besar penyebab anemia defisiensi besi di Indonesia adalah karena kekurangan zat besi (Fe) yang diperlukan dalam pembentukan hemoglobin. (3)

Pengetahuan merupakan salah satu faktor penting untuk membentuk suatu sikap yang utuh. Dimana semakin baik pengetahuan seseorang maka akan semakin baik pula sikap yang akan terbentuk untuk menciptakan suatu tindakan yang baik pula. Ibu hamil yang memiliki pengetahuan yang baik mengenai pentingnya zat besi dan akibat yang ditimbulkan apabila kekurangan zat besi dalam kehamilan pasti akan cenderung membentuk sikap yang positif terhadap kepatuhan sehingga akan timbul tindakan yang patuh dalam mengkonsumsi tablet besi (4)

Dinas Kesehatan Sulawesi Tengah mencatat bahwa AKI tahun 2014 sebesar 190,6 per 100.000 kelahiran hidup. AKI di kabupaten Poso sebesar 142 per 100.000 kelahiran hidup. Untuk cakupan ibu hamil yang mendapatkan tablet Fe dari jumlah ibu hamil 113.182 orang, yang mendapatkan tablet Fe 1 sebanyak 74.903 (66,18\%), sedangkan Fe 3 sebanyak 67.339 (59,50\%). Jumlah ibu hamil yang mengalami anemia defisiensi zat besi adalah $2.584(4,18 \%)$ dari ibu hamil yang memeriksakan kehamilannya pada seluruh sarana kesehatan di Provinsi Sulawesi Tengah. $(5,6)$ 


\section{METODE}

Jenis penelitian yang digunakan YAITU deskriptif analitik dengan menggunakan pendekatan cross sectional. ). Populasi dalam penelitian ini adalah seluruh ibu hamil yang terdapat di wilayah kerja Puskesmas Lawanga Kabupaten Poso periode Juli-Agustus tahun 2016 sebanyak 64 ibu hamil dengan menggunakan tehknik total Sampling. Data kemudian dianalisa dengan menggunakan uji Chi-square.

HASIL

Tabel 1

Distribusi Frekuensi Responden Berdasarkan Pengetahuan di Puskesmas Lawanga Kabupaten Poso

\begin{tabular}{ccc}
\hline Pengetahuan & F & \% \\
\hline Baik & 26 & 56.5 \\
Cukup & 9 & 19.6 \\
Kurang & 11 & 23.9 \\
\hline Total & $\mathbf{4 6}$ & $\mathbf{1 0 0}$ \\
\hline
\end{tabular}

Berdasarkan tabel 5.4 menunjukkan bahwa sebagaian besar responden memmpunyai pengetahuan yang baik yaitu sebanyak 26 responden (56.5\%), sebagian kecil yang memiliki pengetahuan cukup sebanyak 9 responden (19.6\% ) dan yang memiliki pengetahuan kurang yaitu 11 responden (23.9\%).

\section{Tabel 2}

Distribusi Frekuensi Berdasarkan Kepatuhan Mengkonsumsi Tablet Zat Besi (Fe) di Puskesmas Lawanga Kabupaten Poso

\begin{tabular}{ccc}
\hline Kepatuhan & F & \% \\
\hline Patuh & 28 & 60.9 \\
Tidak Patuh & 18 & 39.1 \\
\hline Total & $\mathbf{4 6}$ & $\mathbf{1 0 0}$ \\
\hline
\end{tabular}


Berdasarkan tabel 5.5 menunjukkan bahwa reponden patuh sebanyak 28 responden $(60.9 \%)$ dan reponden yang tidak patuh sebanyak 18 responden $(39.1 \%)$

\section{Tabel 3}

Hubungan Pengetahuan dengan Kepatuhan Ibu Hamil dalam Mengkonsumsi Tablet Zat Besi (Fe) di Puskesmas Lawanga

Kabupaten Poso.

\begin{tabular}{|c|c|c|c|c|c|c|c|}
\hline \multirow{3}{*}{ Pengetahuan } & \multicolumn{4}{|c|}{ Kepatuhan } & \multirow{2}{*}{\multicolumn{2}{|c|}{ Total }} & \multirow[b]{3}{*}{$p-$} \\
\hline & \multicolumn{2}{|c|}{ Patuh } & \multicolumn{2}{|c|}{ Tidak Patuh } & & & \\
\hline & f & $\%$ & f & $\%$ & $\mathbf{f}$ & $\%$ & \\
\hline Baik & 24 & 52.2 & 2 & 4.3 & 26 & 56.5 & value \\
\hline Cukup & 3 & 6.5 & 6 & 13.0 & 9 & 19.6 & 0,000 \\
\hline Kurang & 1 & 2.2 & 10 & 21.7 & 11 & 23.9 & \\
\hline Total & 28 & 60.9 & 18 & 39.1 & 46 & 100 & \\
\hline
\end{tabular}

Berdasarkan tabel di atas menunjukkan bahwa dari 26 responden $(56.5 \%)$ yang memiliki pengetahuan baik, 24 responden (52.2\%) patuh dalam mengkonsumsi tablet zat besi $(\mathrm{Fe})$ dan 2 responden $(4.3 \%)$ tidak patuh dalam mengkonsumsi tablet zat besi $(\mathrm{Fe})$. Kemudian dari 9 responden $(19.6 \%)$ yang memiliki pengetahuan cukup, 3 responden (6.5\%) patuh dalam mengkonsumsi tablet zat besi (Fe) dan 6 responden (13.0\%) tidak patuh. Selanjutnya dari 11 responden (23.9\%) yang memiliki pengetahuan kurang, hanya 1 responden $(2.2 \%)$ yang patuh dalam mengkonsumsi tablet zat besi (Fe) dan 10 responden $(21.7 \%)$ tidak patuh.

Hasil uji chi square menunjukkan nilai p-value $=0,000(p<0,05)$ yang berarti Ha diterima $\mathrm{H}_{0}$ di tolak sehingga dapat disimpulkan bahwa terdapat Hubungan Pengetahuan dengan Kepatuhan Ibu Hamil dalam Mengkonsumsi Tablet Zat Besi (Fe) di Puskesmas Lawanga Kabupaten Poso. 


\section{PEMBAHASAN}

Berdasarkan hasil uji statistik dengan menggunakan chi-square diperoleh adanya hubungan antara pengetahuan ibu hamil dengan kepatuhan mengkonsumsi tablet zat besi (Fe) di Puskesmas Lawanga dimana sebagian besar ibu memiliki pengetahuan yang baik tentang tablet zat besi (Fe). Pada penelitian yang dilakukan oleh Sasfriasa, dkk (2012) menjelaskan bahwa sebagian besar ibu $(82,4 \%)$ memiliki pengetahuan yang baik tentang tablet zat besi (Fe). (7). Penelitian yang sama yang dilakukan Erwin, dkk (2013) menunjukkan bahwa ada hubungan antara pengetahuan ibu hamil dengan kepatuhan mengkonsumsi tablet zat besi (Fe). (8)

Menurut Subarda, (2011) proporsi pengetahuan yang baik akan meningkatkan kepatuhan ibu hamil minum tablet zat besi. Kepatuhan minum tablet zat besi merupakan suatu bentuk perilaku yang dapat terwujud karena adanya pengetahuan yang diperoleh dari luar serta keyakinan dan adanya dorongan dari orang lain (petugas kesehatan, tetangga, teman dekat). (9)

Hal ini juga sesuai dengan pernyataan Ramawati (2008) yang menyatakan pengetahuan memegang peranan yang penting dalam menentukan sikap dan perilaku responden untuk mengkonsumsi tablet besi selama hamil dan mematuhinya.Hal ini menunjukkan bahwa pengetahuan sangat penting peranannya dalam menentukan kepatuhan dalam mengkonsumsi tablet besi. Dengan adanya pengetahuan tentang zat besi, ibu hamil akan tahu bagaimana menyimpan dan menggunakan tablet besi. Memperbaiki konsumsi tablet besi merupakan salah satu bantuan terpenting yang dapat dilakukan untuk meningkatkan kualitas status gizi pada ibu hamil (10)

Berdasarkan hasil penelitian ini diperoleh bahwa tingginya tingkat pengetahuan ibu hamil dan adanya kepatuhan dalam mengkonsumsi tablet Fe disebabkan karena adanya penyuluhan di wilayah kerja Puskesmas Lawanga oleh petugas kesehatan ataupun lembaga kesehatan berkaitan dengan tablet Fe yang harus dikonsumsi oleh ibu hamil selama masa kehamilan. Responden juga menyatakan bahwa ketika mereka memeriksakan kehamilannya pada bidan, mereka dijelaskan tentang tablet zat besi serta manfaat dan akibat jika tidak menkonsumsi tablet tersebut. Selain itu ibu hamil juga diberikan tablet zat besi dari petugas kesehatan.

Menurut Notoatmodjo (2007), pendidikan kesehatan sebagai bagian dari kesehatan masyarakat. Pendidikan kesehatan berfungsi sebagai media atau saran untuk menyediakan kondisi sosio-psikologis sedemikian rupa sehingga individu atau masyarakat berperilaku sesuai 
dengan norma-norma hidup sehat. Sebelum seseorang mengadopsi perilaku baru, ia harus tahu terlebih dahulu apa arti atau manfaat perilaku tersebut bagi dirinya atau keluarganya. (11). Sesuai teori ini, ibu hamil akan melakukan kunjungan pemeriksaan kehamilan dan patuh mengkonsumsi tablet zat besi (Fe) apabila ia tahu apa tujuan dan manfaat dari kunjungan pemeriksaan kehamilan yang dilakukan, mengetahui apa tujuan dan manfaatnya dari mengkonsumsi tablet zat besi (Fe) bagi kesehatannya, dan mengetahui apa bahayanya bila tidak melakukan kunjungan pemeriksaan kehamilan dan mengkonsumsi tablet zat besi $(\mathrm{Fe})$ tersebut.

Semakin banyak pengetahuan ibu hamil tentang pemeliharaan kesehatan dan cara hidup sehat selama masa kehamilan, semakin banyak pertimbangan untuk memlilih jenis-jenis makanan yang bergizi dan manfaat makanan yang bergizi tersebut bagi kesehatan ibu hamil.

\section{KESIMPULAN}

Berdasarkan hasil penelitian ini maka dapat disimpulkan sebagai berikut: 1). Sebagian besar pengetahuan Ibu hamil yaitu memiliki pengetahuan baik. 2) Sebagian besar Ibu hamil patuh dalam mengkonsumsi tablet zat besi (Fe). 3) pengetahuan berhubungan dengan kepatuhan ibu hamil dalam mengkonsumsi tablet zat besi $(\mathrm{Fe})$

\section{DAFTAR PUSTAKA}

1. Departemen Kesehatan RI. Profil Kesehatan Indonesia 2015. Jakarta: Departemen Kesehatan RI; 2016.

2. Saifuddin, AB. Pelayanan Kesehatan Maternal dan Neonatal. Yayasan Bina Pustaka Sarwono Prawirohardjo. Jakarta. 2002

3. Naibaho. Faktor-Faktor yang Berhubungan dengan Kejadian Anemia Gizi Besi pada Ibu Hamil di Wilayah Kerja Puskesmas Parsoburan Kecamatan Habinsaran Kabupaten Toba Samosir. Skripsi Fakultas Kesehatan Masyarakat, Universitas Sumatera Utara. 2015

4. Sunaryo. Psikologi untuk keperawatan. Jakarta: EGC; 2004.

5. Dinkes Sulteng (2015). Profil Kesehatan Sulawesi Tengah. http://www.depkes.sulteng.go.id diakses tanggal 10 Juli 2016

6. Dinkes Kabupaten Poso (2016). Profil Dinas Kesehatan Kabupaten Pos. 2016.

7. Sasfriasa, M., Wuryanto, A., Ratnaningsih, E. (2012). Gambaran Tingkat Pengetahuan dan Kepatuhan Ibu Hamil dalam Mengkonsumsi Tablet Sulfas Feerosus (Fe) di Puskesmas Tlogosari Kulon Semarang. Jurnal Kebidanan Panti Wilasa, Vol. 3 No. 1, Oktober 2012 Hal. 1-6. 
8. Erwin, Rena Regina., Machmud, Rizanda., Utama, Bobby Indra. Hubungan Pengetahuan dan Sikap Ibu Hamil dengan Kepatuhan dalam Mengkonsumsi Tablet Besi di Wilayah Kerja Puskesmas Seberang. Padang. 2013.

9. Subarda. "Pelayanan antenatal care dalam pengelolaan anemia berhubungan dengan kepatuhan ibu hamil minum tablet besi”, Jurnal Gizi Klinik Indonesia. 2011.

10. Ramawati, Dian. "Faktor-Faktor Yang Mempengaruhi Kepatuhan Ibu Hamil Dalam Mengkonsumsi Tablet Besi di Desa Sokaraja Tengah, Kecamatan Sokaraja, Kabupaten Banyumas", Jurnal Keperawatan Soedirman. 2008

11. Notoatmodjo. Perilaku Kesehatan: Teori dan Ilmu Perilaku. Rineke cipta: Jakarta. 2007 